\title{
Promotion of socially responsible business in transport companies in Serbia'
}

\section{Промоција друштвено одговорног пословања у саобраћајним предузећима у Србији}

\author{
Milica Žarevac Bošković \\ Academy of Vocational Studies Šumadija, Kragujevac department, Kragujevac, Republic of Serbia, \\ zarevac.milica@gmail.com \\ Marija Lakićević \\ University of Kragujevac, Faculty of Hotel Management and Tourism Vrnjačka Banja, Vrnjačka Banja, Republic of \\ Serbia, marija.lakicevic@kg.ac.rs

\section{Danijela Pantović} \\ University of Kragujevac, Faculty of Hotel Management and Tourism Vrnjačka Banja, Vrnjačka Banja, Republic of \\ Serbia, danijela.durkalic@kg.ac.rs
}

\begin{abstract}
The topic of this paper represents a relatively new and still evolving term of socially responsible business, with a focus on application of this concept to transport companies. The goal of this paper is to formulate, in accordance with results gained from the study, concrete potential guidelines for more socially responsible business of transport companies in the Republic of Serbia. Considering multiple positive effects of socially responsible business, confirmed by numerous study activities and practical examples, as well as the fact that influences on one of the key external dimensions of socially responsible business - the environment - are most directly connected with transport business, and, finally, observing traffic as connective tissue of the entire economic system that gives purpose to all areas of material production, this paper analyses, in addition to the nature of the link between economic and social performance, the degree of application of socially responsible business in transport companies in the Republic of Serbia as well.
\end{abstract}

Key words: socially responsible business, transport, management

JEL classification: M14, R11

Сажетак: Предмет рада представља релативно нов и још увек еволуирајући термин друштвено одговорног пословања, са фокусом на примени овог концепта у саобраћајним предузећима. Циљ рада је формулисање, у складу са добијеним резултатима истраживања, конкретних могућих смерница за друштвено одговорније пословање саобраћајних предузећа у Републици Србији. Узимајући у обзир бројна истраживања и примере из праксе о потврђеним вишеструким позитивним ефектима друштвено одговорног пословања, као и чињеницу да се утицаји на једну од кључних екстерних димензија друштвено одговорног пословања - животну средину - најдиректније повезују са саобраћајном

\footnotetext{
The paper is a part of the research within the project no. III 46006 -Sustainable agriculture and rural development in the function of accomplishing strategic objectives of the Republic of Serbia in the Danube region, financed by the Ministry of Education, Science and Technological Development of the Republic of Serbia.
}

Corresponding author 
делатношћу, и, коначно, посматрајући саобраћај као везивно ткиво целокупног привредног система које све области материјалне производње чини сврсиходним, у раду се анализира, осим природе везе између економских и друштвених перформанси, и степен примене друштвено одговорног пословања у саобраћајним предузећима у Републици Србији.

Кључне речи: друштвено одговорно пословање, саобраћај, менаџмент

JEЛ класификација: M14, P11

\section{Introduction}

Aside from economic, legal and ethical responsibility, today's businesses are also expected to implement socially responsible behaviour as well. According to Berber, Slavić and Aleksić, the increasing intensity of business changes is a reflection of today's modern business (Berber et al., 2019, p. 5). What is more, social community has certain economic, legal, ethical and philanthropic expectations from companies (Sekulić \& Pavlović, 2018, p. 60). Basically, it is commitment of a company to perform its activities in a way accountable to all its stakeholders (Marković et al., 2020, p. 2). While economic responsibility includes making products that are useful for society, legal responsibility states that all organizations must make sure that each employee is familiar with and adheres to the relevant laws (Sullivan, 2009, p. 5-9). Ethical responsibility represents respect for ethical principles. The most common problem of this responsibility is the ethical dilemmas which unambiguously indicate the fact that, although some ethical questions are easily solved, there are many that do not have obviously correct or incorrect answers.

There is an increased frequency in the case that people want information about a company which justifies its social responsibility and responsibility to the environment, so that they can decide which company to buy from, which company to invest in, and which company to be employed in (Hatch \& Scultz, 2008). Kotler (Kotler \& Keler, 2017) states the following reasons for investing in corporate social responsibility (p. 664): companies must be different; clients will prefer companies that nurture citizen virtues; companies need a decision framework in order to face daily requests for sponsorships, better healthcare, prevention of injuries, protection of the environment and contribution to the community; company leaders and boards must realizes which social pressures and possibilities their companies may face; companies must build a strong positive public reputation in order to neutralize potential negative criticism; employees, investors and partners will be more motivated and more loyal.

The author has selected the analysis of socially responsible business in transport companies for two reasons. First, defined as the fourth area of material production, transport business is represented as the activity without which undisturbed process of social reproduction would be impossible. Second, of all economic activities, transport has the most direct and strongest influence on the environment, as one of the key dimensions of socially responsible business. 


\section{Social responsibility as the concept of modern business}

Although socially responsible business has been debated in expert circles for several decades, it can be said that this is term which is new, evolving, relatively undetermined and insufficiently understandable for general public, and still does not have a generally accepted definition.

The principles connected with the existing definitions of corporate social responsibility include: involvement in the life of a community, accountability, sustainability, transparency, ethical behaviour, respect and inclusion. Socially responsible companies keep to the "triple result" principle, taking into consideration social, economic, and environmental influence (Randjić \& Bogetić, 2012, p. 261). Environmental and social impact are becoming one of the major shareholders' concerns (Denčić-Mihajlkov, 2020, p. 26). Also, according to Redžić $(2018$, p. 16) one of the basis that community impacts is being assessed on is comparison with competition. Furthermore, there is a clear distinction in Anglo-Saxon stances on social responsibility of companies and stances of continental Europe and Japan, where, historically speaking, corporations have developed more as instruments of the state. In the United Kingdom and the United States, companies could freely create profit, provided that no law was being broken. In Japan and Europe, companies were expected to open as many job openings as possible and, for example, to build a state defines system (Hindl, 2006, p. 40). In July 2001, in Brussels, the European Commission declared the so-called "Green Paper", which promotes socially responsible business in countries of the European Union. According to this paper, socially responsible business can be perceived through multiple dimensions, such as (European Commission, 2001): investment in human resources, adjustment to changes, rational use of resources and energy, development of the local community, improvement of partner relationships, human rights, and preservation of the environment. Besides this, importance of corporate social responsibility is also notable as the concept with the great concern in one more international institution such as United Nations (Dragičević-Radičević et al., 2020, p. 331).

According to Mary Coulter, corporate social responsibility is about the existence of various stakeholders and how organizations treat them (Coulter, 2010, p. 61). Stakeholders are persons or groups who have an interest in a company's business and who are influenced that business (Donaldson \& Preston, 1995, p. 65-91). Furthermore, corporate social responsibility represents an obligation of decision makers on specific organizational levels to decide and act in a manner which displays mutual connection of companies and the society (Wood, 1991, p. 691-718). Social responsibility is an obligation of a company to follow a policy, make decisions and undertake actions that benefit society (Bower, 1953). Corporate social responsibility departments are usually included in communications, marketing relations, or corporate foundations department (Abad-Segura et al., 2019). Finally, according to a recent study (Grubor et al., 2020, p. 5) corporate social responsibility represents a balanced concept of economic, social and environmental performances and goals. 


\section{Socially responsible business vs. profitability}

By analysing one of the four basic principles by the founder of scientific management, Frederick Taylor, which implies solid cooperation between managers and employees, we can perceive an analogy of the nature of the relationship between subjects in the aforementioned principle and economic and social aspects of business.

According to Lashinsky (2007), Taylor wrote: "Most of these people believe that essential interests of employees and employers must be conflicted. On the contrary, scientific management is based on a deep conviction that the real interests of those two groups are actually the same. Years of progress are not possible for an employer if it does not imply progress for employees as well. Aside from that, it is possible to give an employee what he wants the most - high salaries - and provide an employer with what he wants the most - low labour cost - for their production operations" (p. 70). Therefore, although there is a clear distinction between those who plan and those who perform, according to Taylor there are no conflicts of interest between managers and employees because their goals are on the same side. On the other hand, the claim about the existence of a negative relationship between economic and social functions is justified. Socially responsible business frequently results in reduced profitability. Milton Friedman, the most prominent supporter of this belief, has claimed that corporate social programs must be paid to an extent, which contributes to the increase in business costs. These costs could either fall on buyers through increased prices, or be borne by the organization. In any case, profitability will decline since buyers will make fewer purchases at higher prices or costs of the organization will increase (Coulter, 2010, p. 63).

However, a deeper analysis indicates a more layered and more complex relationship, between employees and managers, as Taylor explains, as well as between social and economic functions of a company. Aside from clients' needs, modern business imposes a necessary condition for survival on the market on companies, which is satisfaction of needs of stakeholders who represent all interests, external or internal, joined for satisfaction of clients' needs. Furthermore, they rightfully evaluate their fees for their contribution (Adižes, 2012, p. 49). Finding a golden mean in order to fulfil requests of various stakeholders is a complicated process, since they often have a wide array of needs and conflicting expectations (Lerner \& Fryxell, 1994, p. 58-81). Only by stratification and essential understanding of relations between economic and social functions can we 'discover' the transformation of nature of the relationship between these elements, from negative to positive. Besides, Friedman himself has stated that companies should be socially responsible, that the purpose of their existence as parts of society should not be based solely on making profit, but on the aspiration for a greater good, something moral, which undoubtedly leads to ethics. Etymologically, the label ethics is related to the Greek word ethos, something that was established by ancient customs as human actions and behaviour. The word ethos was replaced by the Romans with their own word mos (genitive: moralis) which is the origin of the word moral. Aristotle, as the founder of ethics, was 
responsible to answer whether moral was conditioned by something. According to him, all people by their nature strive to accomplish something good and something that brings happiness. The changed modern society forces the business world to, among other things, adjust their activities more with ethical principles for achieving that (greater) good.

According to Morsing and Spence (2019), "the next wave requires greater sophistication and links across aspects of socially responsible business that address both theoretical and practice-based problems and challenges" (p. 1922). A recent study has shown that buyers are prepared to pay more for goods that are known to be produced in accordance with ethical standards. More importantly, they will buy products that were manufactured contrary to the ethical standards - by exploiting workers, for example - only at huge discounts (Trudel \& Cotte, 2008). Moreover, some individuals believe that ethics affects individuals as well as organizations, and that it should be a part of strategic management (Singer, 1994, p. 192-213). It is clear that misunderstanding or ignoring stakeholders' needs, as well as delays in satisfaction of companies, frequently leads to less profitable business, loss of competitive advantage, and, ultimately, to bankruptcy. Economic performance is a variable category for socially responsible companies as well as for companies that are not socially responsible. Therefore, profitability should not be the primary or the only motive for socially responsible business. Finally, hypothesis in a recent study was that enterprise sustainability led to improved enterprise performance in the long run (Domanović et al., 2020, p. 13).

\section{Significance of socially responsible business in transport companies}

Although numerous studies indicate that the contribution of ecological and safety transport costs in gross domestic product is significantly higher than the contribution of transport in creation of gross domestic product, not one economic system in the world can renounce these activities, which can be explained by one of two reasons for the choice to analyse socially responsible business specifically in transport companies.

Although, according to Marx's labour theory that the nature of a product determines the nature of the activity, transport can be defined here as the service sector, considering that the result of this activity is a service (of transport), it is still defined as the fourth area of material production due to its significantly vital value for the functioning of the entire economy. Each production process begins with a single goal, which is to give consumption value to a product. This goal is realized at the moment when the product is consumed by someone for whom the product was initially intended. However, the most common place of production and place of consumption are separate, by time as well as territory. In order for a manufactured product to be consumed, it must be transported from the manufacturing spot to the consumption spot, i.e. the market, after which its consumption value has been realized. Each production process ends when the consumption value is realized, otherwise each and entire production process would be incomplete, meaningless and useless. The activity which 'erases' time and space between a production spot and consumption spot, 
thanks to which each production can be complete, meaningful and useful, is the transport activity. That is why transport is an 'extension' of the entire process of social reproduction, its connective tissue, the bridge without which that process would be halted and incomplete.

Furthermore, considering that socially responsible business answers many environmental questions stemming from performing the transport activity, permanent promotion of the concept of socially responsible business in this activity is of huge significance. Removal of green areas, fragmentation of natural habitats, climate change, exhaustion of non-renewable natural resources and energy consumption, noise, pollution of air, soil, and water, these are only some of negative influences of transport on the environment. Congestion of transport infrastructure (roads, railroad network, airways and airports) is a distinct problem on certain transport routes and corridors in Europe. With increased intensity of traffic, the number of traffic accidents is rapidly increasing and the number of casualties on the roads in Europe amounts to several tens of thousands each year, which is equal to casualties of a regional war (Božić et al., 2017, p. 142). When it comes to the Republic of Serbia, the Traffic Safety Act has brought certain changes in the number of casualties, which is currently insufficient for a long-term increase in traffic safety (Petrović et al., 2020, p. 483). Additionally, there is no doubt that one activity always results in benefit for some, and expense for others, which leads us to the term distortion, which exists if the marginal expense of society in relation to production of a good (e.g. transport services) is not equal to the marginal benefit of a society from the consumption of that good (Begg et al., 2010, p. 264). When it comes to the transport sector, a problem appears since there is no market for things such as noise, pollution or congestion, externalities which are inseparable from transport companies and transport activity as a whole. Thus, a market that does not exist cannot bring balance between a marginal benefit that one party gains by causing congestion, for example, and a marginal cost of this externality borne by another party.

Aside on a macro level, application of a strategy for sustainable transport is important on the level of individual companies as well. Some advantages of environmentally oriented transport companies would include: maintaining competitive advantage, better market image, better communication with clients, support by a larger community, etc. One of the ways for a traffic company to fulfil stakeholders' requests related to social responsibility is a proactive strategy, i.e. a strategy with which a company predicts responsibility for a problem that has not appeared yet. An example of a good practice is the company Honda Motors. This company has announced that they will include side air curtains (lowered from the headliner and protecting passengers' heads) and front side airbags (which are installed in the doors and protect from impacts from the side) in the standard equipment package for all their cars. Although manufacturers of more expensive cars, such as Lexus and Volvo have already offered these safety measures, the company Honda was the first to include them in the standard equipment package for all its models (Williams, 2010, p. 75). 


\section{Methodology}

\subsection{Aim of research}

The goal of the survey was to determine the level of application of socially responsible business in surveyed companies. The survey was completely anonymous, which contributed to honesty and objectiveness of the respondents while answering, which, finally, certainly increased the significance of the survey and the quality of the results.

\subsection{Method}

According to the level of conclusion generalization, the study was operative since a relatively small sample of 50 respondents was used. An explicative type of empiricalexperimental method was used, since the study included collecting field data. Although it originates from a complex modern business environment, with equally complex and numerous needs and requests, the hypothesis formulation is fairly simple:

Economic performance is better in (transport) companies which lead their business in a socially responsible manner, than in the companies who do not.

The confirmation of the hypothesis could additionally motivate transport companies to conduct more socially responsible business, taking into consideration the positive relationship between socially responsible business and the primary goal of every organization, profitability, in the hypothesis.

\subsection{Description of the sample survey}

The study was performed in August, 2020, with a sample of 50 respondents who were, at the time of the study, employed at 5 transport companies in the Republic of Serbia, four of which were in private property and one in state property. 10 respondents were surveyed in each company, on positions of top management, middle line management and first line management. The surveyed companies were marked with letters A, B, C, D and E. Economic performance of the companies was the criterion for assigning specific letter labels, in the following manner: the company labelled A has the best, and the company with the label $\mathrm{E}$ has the worst economic performance.

\subsection{Procedures}

A closed-ended survey was used as the study technique. By using the model of socially responsible business in accordance with the "Green Paper", we formulated two types of ten survey questions. For the first type of questions, the respondents were to answer with a 'yes' or 'no' (Table 1), and for the second type the respondents were to grade levels of application of a specific dimension of socially responsible business. The grades ranged from 1 to 5 , with the following interpretations: grade 1 as very high, grade 2 as relatively high, grade 3 as moderate, grade 4 as relatively low, and grade 5 as very low level of application of a specific dimension of socially responsible business (Table 2). 


\subsection{Data analysis}

Answers for the first group of questions are provided in Table 1.

Table 1: The results for the examination regarding the level of application of socially responsible business in transport companies for the first group of questions (in percent, \%)

\begin{tabular}{|c|c|c|c|c|c|c|c|c|c|c|c|c|}
\hline \multirow{2}{*}{$\begin{array}{l}\text { Questions } \\
\text { Companies" } \\
\text { responses }\end{array}$} & \multicolumn{2}{|c|}{$\begin{array}{c}\text { Have you or one } \\
\text { of your } \\
\text { colleagues ever } \\
\text { been exposed to } \\
\text { some form of } \\
\text { discrimination? }\end{array}$} & \multicolumn{2}{|c|}{$\begin{array}{c}\text { Are ethical } \\
\text { principles } \\
\text { respected in } \\
\text { your } \\
\text { workplace? }\end{array}$} & \multicolumn{2}{|c|}{$\begin{array}{l}\text { Does your } \\
\text { company } \\
\text { participate in } \\
\text { public } \\
\text { benefit } \\
\text { campaigns? }\end{array}$} & \multicolumn{2}{|c|}{$\begin{array}{l}\text { Is the } \\
\text { strategy for } \\
\text { use of } \\
\text { healthier } \\
\text { technology } \\
\text { applied? }\end{array}$} & \multicolumn{2}{|c|}{$\begin{array}{l}\text { Are educative } \\
\text { programs } \\
\text { regarding } \\
\text { environment } \\
\text { protection } \\
\text { organized? }\end{array}$} & \multicolumn{2}{|c|}{$\begin{array}{l}\text { Is the } \\
\text { strategy for } \\
\text { reduction of } \\
\text { emission of } \\
\text { harmful } \\
\text { materials } \\
\text { adopted? }\end{array}$} \\
\hline & yes & no & yes & no & yes & no & yes & no & yes & no & yes & no \\
\hline $\begin{array}{l}\text { Company } \\
\text { "A", }\end{array}$ & 0 & 100 & 90 & 10 & 70 & 30 & 80 & 20 & 90 & 10 & 100 & 0 \\
\hline $\begin{array}{l}\text { Company } \\
\text { "'B", }\end{array}$ & 10 & 90 & 80 & 20 & 80 & 20 & 90 & 10 & 100 & 0 & 70 & 30 \\
\hline $\begin{array}{l}\text { Company } \\
\text { "'C', }\end{array}$ & 50 & 50 & 40 & 60 & 60 & 40 & 70 & 30 & 50 & 50 & 70 & 30 \\
\hline $\begin{array}{l}\text { Company } \\
\text { "D," }\end{array}$ & 80 & 20 & 30 & 70 & 60 & 40 & 30 & 70 & 30 & 70 & 20 & 80 \\
\hline $\begin{array}{l}\text { Company } \\
\text { "'E,, }\end{array}$ & 80 & 20 & 20 & 80 & 0 & 100 & 0 & 100 & 0 & 100 & 0 & 100 \\
\hline
\end{tabular}

Source: the authors' research results

In companies $\mathrm{A}$ and $\mathrm{B}$ there were almost no forms of discriminatory behaviour recorded (only 1 affirmative answer in the company $\mathrm{B}$ ), while the situation is less favourable in company $\mathrm{C}$, and even more so in companies $\mathrm{D}$ and $\mathrm{E}$ (8 affirmative answers were recorded for each, or $80 \%$ ). A high level of respect for ethical business principles was present in companies $\mathrm{A}$ and $\mathrm{B}$, while that level was significantly lower in other companies. Company B had the greatest participation in public benefit campaigns, while complete absence of participation was recorded in company $\mathrm{E}$ (zero affirmative answers, i.e. 10 negative answers, or 100\%). While usage of healthier technology is implemented in companies $\mathrm{A}$ and $\mathrm{B}$, this implementation is completely absent in company $\mathrm{E}$ (zero affirmative answers). In companies $\mathrm{A}$ and $\mathrm{B}$ there are occasional educative programs related to protection of the environment, while in other companies this education is almost absent (10 negative answers were recorded for company E, or $100 \%$ ). Regarding the application of a strategy for reduction of emission of harmful materials, the absolute application, with ten affirmative answers, was recorded in company A, while the absolute absence of application, with ten negative answers, was recorded in company E. Answers for the second group of questions are provided in Table 2. 
Table 2: The results for the examination regarding the level of application of socially responsible business in transport companies for the second group of questions (in percent, \%)

\begin{tabular}{|c|c|c|c|c|c|c|c|c|c|c|c|c|c|c|c|c|c|c|c|c|}
\hline \multirow{2}{*}{$\begin{array}{l}\text { Questions } \\
\text { Companies' } \\
\text { Tesponses }\end{array}$} & \multicolumn{5}{|c|}{$\begin{array}{l}\text { Evaluate the level of help } \\
\text { and support during the } \\
\text { company's restructuring }\end{array}$} & \multicolumn{5}{|c|}{$\begin{array}{l}\text { Evaluate the level of the } \\
\text { company's preservation } \\
\text { of natural resources }\end{array}$} & \multicolumn{5}{|c|}{$\begin{array}{c}\text { Evaluate the level of the } \\
\text { company's contribution } \\
\text { to the local community } \\
\text { development }\end{array}$} & \multicolumn{5}{|c|}{$\begin{array}{l}\text { Evaluate the level of } \\
\text { responsibility when using } \\
\text { non-renewable resources }\end{array}$} \\
\hline & 1 & 2 & 3 & 4 & 5 & 1 & 2 & 3 & 4 & 5 & 1 & 2 & 3 & 4 & 5 & 1 & 2 & 3 & 4 & 5 \\
\hline $\begin{array}{l}\text { Company } \\
\text { "A" }\end{array}$ & 80 & 20 & & & & 80 & 20 & & & & 70 & 20 & 10 & & & 100 & & & & \\
\hline $\begin{array}{l}\text { Company } \\
\text { "'B", }\end{array}$ & 70 & 30 & & & & 80 & 20 & & & & 70 & 10 & 20 & & & 80 & 20 & & & \\
\hline $\begin{array}{l}\text { Company } \\
\text { "C", }\end{array}$ & & & 50 & 50 & & & & & 50 & 50 & & & 40 & 20 & 40 & & & 30 & 20 & 50 \\
\hline $\begin{array}{l}\text { Company } \\
\text { "D" }\end{array}$ & & & & 50 & 50 & & & & 60 & 40 & & & & 80 & 20 & & & & 30 & 70 \\
\hline $\begin{array}{l}\text { Company } \\
\text { "E", }\end{array}$ & & & & 90 & 10 & & & & 10 & 90 & & & & 20 & 80 & & & & & 100 \\
\hline
\end{tabular}

Source: the authors' research results

In company A most respondents graded the level of help and support during the company's restructure with the highest grade (very high), while in company E as many as 9 respondents $(90 \%)$ chose the grade four, as a relatively low level of application of a specific dimension of socially responsible business. Regarding the level of preservation of natural resources, the highest grades were recorded in companies A and B, and the lowest grades in company E (9 respondents, or $90 \%$, graded the level of application of the given dimension as very low). The highest level of contribution to the local community development was recorded in companies $\mathrm{A}$ and $\mathrm{B}$, and the lowest level in company E. Very high level of responsible usage of non-renewable resources was recorded in company A (all 10 respondents, or $100 \%$, graded the level of application of this dimension with the highest grade), while in company $\mathrm{E}$ an opposite situation was recorded - all 10 respondents, or $100 \%$, graded the level of application of this dimension with the lowest grade, very low.

In the companies with the best economic performance, which are companies A and $\mathrm{B}$, the highest level of application of socially responsible business was recorded, slightly lower level of application at companies $\mathrm{C}$ and $\mathrm{D}$, while the business practice with the highest deviation from the concept of socially responsible business was recorded in company E, which had the lowest economic performance.

The company labelled $\mathrm{C}$ is the only state-owned surveyed company. The results of the research indicate a relatively moderate degree of application of socially responsible business, since in the first group of questions, out of a total of 50 answers, 34 are affirmative (68\%) and 26 negative (32\%). In addition, the average grade of the degree of application of a specific dimension of corporate social responsibility is 4.15 , which is interpreted as a relatively low grade.

Table 3. Number of managers according to the level of management in the surveyed companies (in percent, \%) 


\begin{tabular}{|l|l|l|l|}
\hline $\begin{array}{l}\text { Companies/Level of } \\
\text { management }\end{array}$ & $\begin{array}{l}\text { Top } \\
\text { management }\end{array}$ & $\begin{array}{l}\text { Middle line } \\
\text { management }\end{array}$ & $\begin{array}{l}\text { First line } \\
\text { management }\end{array}$ \\
\hline Company 'A' & 10 & 30 & 60 \\
\hline Company 'B'" & 20 & 30 & 50 \\
\hline Company 'CC' & 40 & 30 & 30 \\
\hline Company 'D" & 40 & 30 & 30 \\
\hline Company ''E' & 60 & 30 & 10 \\
\hline
\end{tabular}

Source: the authors' research results

In company $\mathrm{A}$ as a company with the best economic performance, the highest number of affirmative answers to the first group of questions and the highest assessments of the degree of application of a specific dimension of corporate social responsibility in the second group of questions, was given by first line managers (6 respondents or $60 \%$ of the total respondents), followed by middle managers (3 respondents or $30 \%$ of the total respondents), and only one respondent from the position of top management $(10 \%$ of the total respondents). The opposite conclusion can be drawn for the company $\mathrm{E}$ as the company with the weakest economic performance. The highest number of negative answers to the first group of questions and the lowest assessments of the degree of application of a specific dimension of corporate social responsibility in the second group of questions, was given by top management ( 6 respondents or $60 \%$ of the total respondents), followed by middle managers ( 3 respondents or $30 \%$ of the total respondents), and only one respondent from the position of first line management (10\% of the total respondents).

Aside from a moderate level of application of socially responsible business practices, as well as the positive relationship between levels of application of socially responsible business and economic performance, the study was also meant to confirm a significant overlap in differences in the levels of application of socially responsible business and differences in economic performance. Although the study results have confirmed a positive relationship between levels of application of socially responsible business and levels of economic performance (observing data in Tables 1 and 2, it is easily concluded that from the most profitable company A to the least profitable company $\mathrm{E}$ the level of application of socially responsible business decreases, respectively), aside from the unexpectedly low level of application of socially responsible business, it is also surprising to find out that differences in the level of application of socially responsible business are significantly above differences in economic performance of these companies. Partially met expectations indicate the conclusion that the hypothesis of the paper itself can only be accepted partially and conditionally.

\section{Conclusion}

While the traditional method places focus on the company's profit as the primary goal of business, socially responsible economy is directed at establishing economic activities in the context of a social system. With the increasing pressure of population growth and the environment, we must modify either our goals or methods that we choose to accomplish them (Harris, 2009, p. 29). Since the effects of transport activity are directly related to the 
environment, it is crucial to motivate transport companies to conduct their business in a more socially responsible manner. Considering the overall significance of application of socially responsible business, in accordance with the study results, the following are concrete potential guidelines for more socially responsible business of transport companies in the Republic of Serbia:

- Formulating a strategy in which models directed at stakeholders are mutually harmonized. Harmonization of goals such as fulfilling stakeholders' needs, performing activities for mutual benefit, satisfactory profitability and interest of various stakeholder companies

- Experience of numerous successful managers undoubtedly indicate the fact that the main difference between the leading companies and their competitors is the treatment of employees by the management. One of the management practices, with the treatment of employees as the essential source of competitiveness, includes among other things the following: ensuring safety of the workplace, organized training and developing employees' skills, selective employment, absence of status differences, etc.

- Promoting behaviour directed at strengthening relations. Contrary to the opportunistic behaviour, in which one party gains benefit at the other party's expense, the management of a company needs to focus on strengthening a long-lasting and positive relationship with buyers and suppliers.

- Determining and maintaining appropriate organization culture. Consistency of organization culture should be ensured by actively transferring organizational values, beliefs and stances.

- Defining a vision with a focus on the values of socially responsible business. A vision of a transport company might be: "the most respected automobile company in Europe". Aside from clearly indicating the purpose of the company's existence to the employees (production of cars) it also indicated the most important values (success and respect).

- Introduction and application of a program adjusted to ethical principles. Encouraging ethical behaviour at work and implementing a penal policy for inappropriate behaviour at work. Some of the ethical principles could be: the principle of state regulations, personal virtues, individual's rights, utilitarianism, etc.

- Formulation and implementation of a proactive strategy. This strategy represents one of the best forms of answers to the society's requests, since it predicts a problem and, before it appears, the company undertakes the responsibility of solving that problem.

- Helping and supporting employees during organizational changes. Some of the forms of help could be: presenting the reason for change, showing empathy, guaranteeing job safety, organizing education for employees in order to facilitate fulfilment of new requests, etc. 
- Establishing and respecting a penal policy for all forms of discriminatory behaviour. Some of the most common forms of discrimination at work are related to: race and ethnics, disability, age, or sex.

- Employing charismatic ethical leaders. Ethical leaders use their powers to serve others, they instigate two-way communication since they value other people's opinions, they emphasize the importance of employees' improvement, etc.

- Minimizing transport costs. Some of the measures for accomplishing this goal could be: shorter transport routes, construction of transport infrastructure, computerization of dispatch systems, automation of reservations and issuing tickets, etc.

- Maximizing traffic safety. Better availability of new techniques to traffic participants, as well as consistent application primarily of preventive-educational, and then repressive measures.

- Rational consumption of energy. This goal can be realized by application of new scientific discoveries.

\section{References}

Abad-Segura, E., Cortés-García, F.J., \& Belmonte-Ureña, L.J. (2019).The sustainable approach to corporate social responsibility: A global analysis and future trends. Sustainability, 11(19), 5382. Doi: https://doi.org/10.3390/su11195382

Adižes, I.K. (2012). Adižes o menadžmentu. Beograd: Hesperia Edu.

Begg, D., Fischer, S., \& Dornbusch, R. (2010). Ekonomija. Beograd: Data Status.

Berber, N., Slavić, A., \& Aleksić, M. (2019). The relationship between corporate social responsibility and corporate governance. Ekonomika, 65(3), 1-12. Doi: https://doi.org/10.5937/ekonomika1903001B

Bower, H.R. (1953). Social Responsibilities of the Businessman. New York: Harper and Row.

Božić, V., Aćimović S. \& Mijušković M. V. (2017). Ekonomija saobraćaja. Beograd: Centar za izdavačku delatnost, Ekonomski fakultet.

Coulter, M. (2010). Strategijski menadžment na delu. Beograd: Data Status.

Denčić-Mihajlov, K. (2020). Does sustainability matter in mergers and acquisitions? The case of the Serbian food industry. Economics of Agriculture, 67(1), 25-36. Doi: https://doi.org/10.5937/ekoPolj2001025D

Domanović, V., Bogićević, J., \& Krstić, B. (2020). Effects of enterprise sustainability on performance. Economics of Sustainable Development, 4(1), 11-23. Doi: https://doi.org/10.5937/ESD2001011D

Donaldson, T., \& Preston, L. E. (1995). The stakeholder theory of the corporation: Concepts, evidence, and implications. Academy of Management Review, 20(1), 65-91. Doi: https://doi.org/10.5465/amr.1995.9503271992 
Dragičević-Radičević, T., Stanojević, L., Milanović, V., Katanić, Z., \& TodosijevićLazović, S. (2020). Corporate social responsibility and new technologies in food industry, the public perception: case study of Vojvodina. Ekonomika poljoprivrede, 67(2), 329-343. Doi: https://doi.org/10.5937/ekoPolj2002329D

European Commission. (2001, July). Green Paper: Promoting a European Framework for Corporate Social Responsibility. Retrieved September, 5th, 2020, from https://ec.europa.eu/commission/presscorner/detail/en/DOC $01 \_9$

Grubor, A., Berber, N., Aleksić, M. \& Bjekić, R. (2020). The influence of corporate social responsibility on organizational performances: a research in AP Vojvodina. Anali Ekonomskog Fakulteta u Subotici, 56(43), 3-13. Doi: https://doi.org/10.5937/AnEkSub2001003G

Harris, M. J. (2009). Ekonomija životne sredine i prirodnih resursa. Beograd: Data Status. Hatch, J.M., \& Schultz, M. (2008). Taking Brand Initiative: How Companies Can Align Strategy, Culture, and Identity through corporate Branding. San Francisco.

Hindl, T. (2006). Menadžment. Novi Sad: Adižes.

Kotler, F., \& Keler K. (2017). Marketing menadžment. Beograd: Data Status.

Lashinsky, A. (2007). Google is no. 1: Search and Enjoy. Fortune (January 29).

Lerner, L. D., \& Fryxell, G. E. (1994). CEO stakeholder attitudes and corporate social activity in the Fortune 500. Business \& Society, 33(1), 58-81. Doi: https://doi.org/10.1177\%2F000765039403300104

Marković, M., Krstić, B., \& Rađenović, T. (2020). Circular economy and sustainable development. Economics of Sustainable Development, 4(1), 1-9. Doi: https://doi.org/10.5937/ESD2001001M

Morsing, M., \& Spence, L. (2019). Corporate social responsibility (CSR) communication and small and medium sized enterprises: the governmentality dilemma of explicit and implicit CSR communication. Human Relations, 72(12), 1920-1947. Doi: https://doi.org/10.1177\%2F0018726718804306

Petrović, A. A., Jovanović, D. M., \& Stanojević, P. T. (2020). Changes in the number of traffic accidents fatalities in the Republic of Serbia. Tehnika, 75(4), 479-484..

Randjić, D., \& Bogetić S. (2012). Menadžment u saobraćaju. Beograd: Beogradska poslovna škola, Visoka škola strukovnih studija.

Redžić, D. (2018). Significance of quality in the tourism industry: research study on the perception of stakeholders in tourism. Hotel and Tourism Management, 6(2), 11-20. Doi: https://doi.org/10.5937/menhottur1802011R

Sekulić, V., \& Pavlović, M. (2018). Corporate social responsibility in relations with social community: determinants, development, management aspects. Ekonomika, 64(4), 59-69. Doi: https://doi.org/10.5937/ekonomika1804057S

Singer, A. E. (1994). Strategy as moral philosophy. Strategic Management Journal, 15(3), 191-213. Doi: https://doi.org/10.1002/smj.4250150302 
Sullivan, E. A. (2009). Play by the new rules. Marketing News, 43(19), 5-9.

Trudel, R., \& Cotte, J. (2008). Does Being Ethical Pay? The Wall Street Journal.

Williams, C. (2010). Principi menadžmenta. Beograd: Data Status.

Wood, D.J. (1991). Corporate social performance revisited. Academy of Management Review 691-718 Available on $19 / 12 / 2020$

on: https://questrompublish.bu.edu/rtrudel/TC\%20WSJ\%202008.pdf 